\title{
The continuum of Information Systems project success: Reflecting on the correlation between project success dimensions
}

\author{
Nazeer Joseph (iD, Carl Marnewick (i) \\ University of Johannesburg, Department of Applied Information Systems, Johannesburg, South Africa
}

\begin{abstract}
Information systems (IS) project success has been a perennial bane of many researchers. Although there are short, medium and long-term dimensions to success, the reality is that they are inseparably linked. Time plays a significant role as a stakeholder, such as a project manager who has short-term interests. In contrast, a business executive has long-term interests for the organisation as a whole. Project success is arguably a continuum where each dimension plays a role in realising long-term benefits for the organisation. This research investigates IS projects specifically to understand the argued correlation between short, medium and long-term project success dimensions. A total of 612 valid responses were collected through an online questionnaire. Quantitative analysis through PLS-SEM was conducted to reveal the correlation between success dimensions. The overall implication is that short-term IS project success does not directly correlate with long-term IS project success. However, there is a clear correlation between the time phases of IS project success. This research shows medium-term success mediates the relationship and correlation of short and long-term success. While literature acknowledges the relationship literature, this research confirms this notion and proves a significant correlation between each IS project success dimension over time.
\end{abstract}

Keywords: Information system projects, project success, project success constructs, project dimensions, project lifecycle

Categories: • Applied computing $\sim$ Operations research

Email:

Nazeer Joseph njoseph@uj.ac.za (CORRESPONDING),

Carl Marnewick cmarnewick@uj.ac.za
Article history:

Received: 7 August 2020

Accepted: 17 February 2021

Available online: 12 July 2021

\footnotetext{
Joseph, N. and Marnewick, C. (2021). The continuum of Information Systems project success: Reflecting on the correlation between project success dimensions. South African Computer Journal 33(1), 37-58. https://doi.org/ $10.18489 /$ sacj.v33i1.873

Copyright (C) the author(s); published under a Creative Commons NonCommercial 4.0 License (CC BY-NC 4.0). SACJ is a publication of the South African Institute of Computer Scientists and Information Technologists. ISSN 1015-7999 (print) ISSN 2313-7835 (online).
} 


\section{INTRODUCTION}

Information systems (IS) project success has been a perennial bane of many researchers (Marnewick et al., 2017; Thomas \& Fernández, 2008; Wateridge, 1998). A plethora of views exists in the IS project space with marginal consensus regarding what constitutes success. The general concept of project success has evolved from the triple constraint to be more inclusive of stakeholder and organisational dimensions (Albert et al., 2017). An emergent pattern is assessing IS project success across multiple dimensions as relying on immediate or short-term success is unjust in determining overall project success (Marnewick et al., 2017; Sulistiyani \& Tyas, 2019). A practical example is the Sydney Opera House which exceeded time and cost but was a long-term success. Although there are short, medium and long-term dimensions to success, the reality is that they are inseparably linked (Pinkerton, 2003; Shenhar et al., 2001). Fleron et al. (2019) explore the "Fata Morgana" or mirage effect where success changes throughout an IS project's lifecycle as well as beyond project delivery. Zwikael and Meredith (In Press) agree and note how success changes as time progresses and conditions change. Time plays a significant role as a stakeholder such as a project manager has short-term interests while a business executive has long-term interests for the organisation as a whole (Zwikael \& Meredith, 2018). The focus should also, therefore, be placed on the success of the project output and how it is accepted and used within the organisational context (Petter et al., 2008). Subsequently, an argument is made for distinct yet related project success dimensions (Petter et al., 2013). That is, project success should arguably be viewed as a continuum where each dimension plays a role in realising long-term benefits for the organisation. Emphasis has long been placed on project management success with little cognisance of the impact and value created long after a project is completed (Artto et al., 2016). Zwikael and Meredith (In Press) explored the underlying connection between short, medium and long-term success and validated the need to assess project success over time. However, the study had a generic project focus and explored project success time dimensions from a stakeholder perspective.

This research investigates IS projects specifically to understand the argued connection between short, medium and long-term project success dimensions. Furthermore, the aim is to contextualise the connection between the three dimensions from a holistic IS project perspective. This research aims to expand on prior research and determine the correlation between the three continuum dimensions of IS project success. The following research question posed: What is the correlation between the short, medium and long-term dimensions in IS project success?

The remainder of the paper is structured as follows. The second section conceptualises and provides a theoretical background of the project success continuum. The third section presents the research methods adopted while the fourth section presents the results of this research. The final section discusses the implications and conclusions of the results while presenting research limitations and avenues for future studies. 


\section{THEORETICAL BACKGROUND}

\subsection{The project success continuum}

A systematic literature review by Albert et al. (2017) shows only one source of IS project success, i.e., Wateridge (1995). Wateridge focused on the hard criteria of project performance and quality as well as the soft criteria of customers and end-user satisfaction. Albert et al. (2017) note contention around the term "quality" as it is ambiguous and has multiple meanings. The same can, however, be said for other criteria as they can be perceived differently by the involved stakeholders (Davis, 2014). Nguyen et al. (2017) performed a systematic literature review on IS project success specifically and found that conceptual literature outweighs empirical literature. Furthermore, there are three main views of IS project success: (i) acceptance and use of technology, (ii) IS success and (iii) project success. These three views suggest IS project success is a combination of the project, the solution and the solution's technology effectiveness. The overall message from literature is that IS project success cannot be viewed through a single lens and multiple constructs exist to determine the real extent of success (Shenhar et al., 2001). Bannerman and Thorogood (2012) acknowledged this and developed a multi-dimensional model of IS project success. The constructs include process success (technical), project management success (project), product/deliverable success (client/user), business success (organisation) and strategic success (industry). These constructs were conceptualised as being independent and measured at different points in time. However, determining success at a specific point in time may negate successes associated with internal and external elements beyond a project. Pinkerton (2003) asserts, "If the venture is not a success, neither is the project". IS project success cannot be seen as a black box as this forfeits the interconnected nature of success (Pankratz \& Basten, 2018). Pankratz and Basten (2018) investigated the relationship between IS project success criteria and factors and revealed an interconnected network between the two concepts. That is, no criteria or factor exists in isolation as they are inherently connected. Hughes et al. (2019) explored the interconnected structure of IS project success and showed how factors influence and reinforce each other when determining success. Although Bannerman and Thorogood (2012) assert each construct exists in a different timeframe, Joseph (2017) and Marnewick et al. (2017) argue the symbiotic conceptualisation of success where each construct functions together. Shenhar et al. (2001) argue that a project can be successful in the short-term but less so in the long-term and vice versa. There is a lag effect between short and long-term success as a considerable time could lapse before fully assessing success. IS project success should arguably be viewed as a continuum where a collection of success criteria and constructs progressively realise success over time. The continuum therefore exists across three time dimensions: (i) short-term success, (ii) medium-term success and (iii) long-term success.

The project success continuum can be contextualised through the project lifecycle lens. Archibald et al. (2012) reflects on the extended project lifecycle model presented in the Association for Project Management Body of Knowledge and notes how project closure is not the actual end of a project. Project closure should be followed by post-project evaluation as 
this includes medium and long-term aspects such as benefits management. Moreover, their analysis reveals how project management should be extended beyond project delivery and address the strategic aspect of a project. Studies such as Saad et al. (2002), Brady et al. (2005) and Armenia et al. (2019) have conceptually and empirically developed an extended project lifecycle view. An argument is made for a holistic view of project success and the expected and realised medium and long-term benefits (Armenia et al., 2019; Saad et al., 2002). Brady et al. (2005) speaks to IS projects specifically and argues how projects have traditionally been handed over with little awareness of operational resources and support required to improve IS delivery and usage throughout its lifespan. Armenia et al. (2019) conclude by arguing the need to understand the operational and strategic implications of projects when viewing projects from an extended project lifecycle lens. The industry has acknowledged the need for an extended project lifecycle as shown in the Accelerated SAP (2009), Oracle Unified Method (2015) and Microsoft Sure Step (2013) project management methodologies. IS industry stalwarts SAP, Oracle and Microsoft include an operation or production phase as part of the project lifecycle. They recognised that delivered IS require continuous support and refinement to facilitate medium and long-term operational benefits within an organisation. Figure 1 illustrates the continuum of IS project success and the intricate connection between success constructs and dimensions along the project lifecycle.

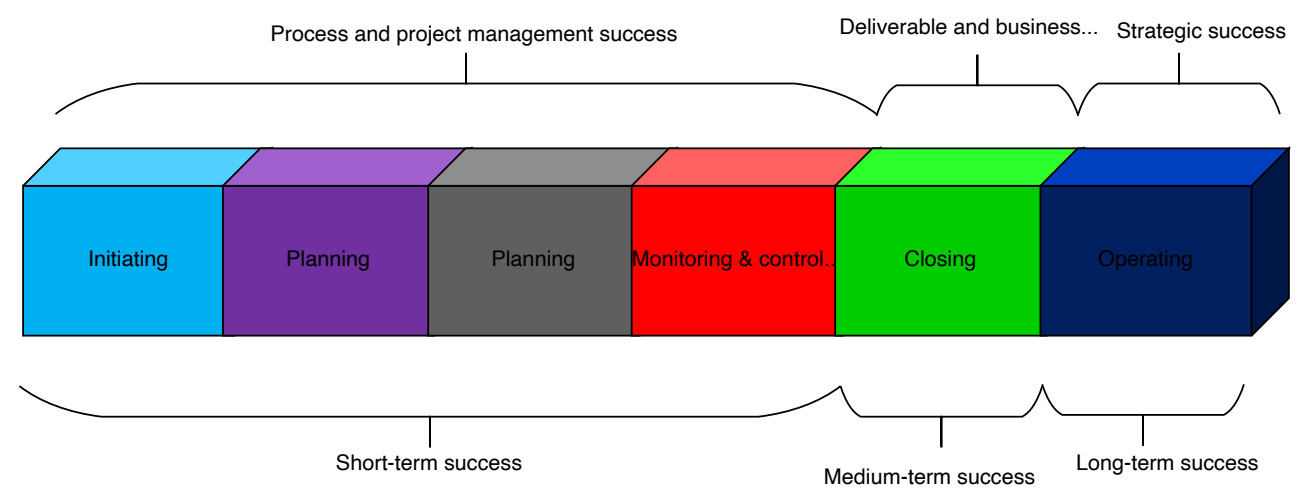

Figure 1: The continuum of IS project success

\subsection{Short-term success}

The most common assessment of short-term success is the triple constraint (Baccarini, 1999; Shenhar et al., 2001). Short-term success focuses on the efficient management of resources to maintain the triple constraint status quo of a project. Quantitative measures such as time 
and cost are tangible and simpler to assess (Ika, 2009). The immediate assessment provides instant snapshots that can be compared during and post-project execution. While this provides instant insight into project efficiencies, it is a scapegoat for other project influences (Albert et al., 2017; Hughes et al., 2019). Qualitative measures such as scope and/or quality are generally intangible as there are varying perceptions (Davis, 2014). The scope should have a clear definition but in reality, it could change multiple times during a project (Yap et al., 2019). Inevitable change manifests blurred interpretations of what is in and out of scope as well as the definition of project quality (Mirza et al., 2013).

Short-term success is analogous to project management success (Baccarini, 1999) and project efficiency (Shenhar et al., 2001) from a generalised view. Research in the IS project domain expands on these constructs. Bannerman and Thorogood (2012) assess short-term IS project success in terms of process success and project management success. Project management success speaks to the triple constraint. Conversely, process success embodies the underlying processes applied to an IS project (Bannerman \& Thorogood, 2012). This construct assesses the project governance and development methodology as well as risk, configuration, change and quality management processes. While Nguyen et al. (2017), Fleron et al. (2019) and Sulistiyani and Tyas (2019) mention process success, they do not explicitly argue for assessing the processes executed during IS projects. Conversely, Hughes et al. (2019) empirically validated the importance of processes such as resistance, post-mortem, audit and benefits management. They, however, did not validate how these processes affect success over time. Pankratz and Basten (2018) emphasise the role of process success for IS projects as it facilitates team member motivation through a transparent and clear understanding of processes. Process success is not a standalone short-term measure but a concise and empirical understanding of its impact over time is still missing (Joseph, 2017).

\subsection{Medium-term success}

Success occurs in multiple forms that are not always apparent. Project success in the 21st century has evolved to explore, acknowledge and contextualise constructs such as product and business success (Cooke-Davies, 2002; Ika, 2009). Baccarini (1999) asserts project goal, project purpose and stakeholder satisfaction of the final project output as the key pillars of a project's product success. The challenge of these success measures is that they are considered predicted benefits and are not evident until after the project is completed (CookeDavies, 2002). Fleron et al. (2019) refer to the "Fata Morgana" phenomenon where success is an illusion or something that initially appears to be real but changes as you near it. In the IS project context, this is particularly true as product success is not explicitly clear even when certain criteria are measured and achieved. Bannerman and Thorogood (2012) elucidate the IS project product/deliverable success construct as meeting client and user requirements, specifications and expectations. Moreover, product success implies the IS solution delivered is accepted and used to realise benefits for the client and user. This construct should arguably be integrated and directed by project processes such as resistance and benefits management 
(Hughes et al., 2019). The perpetual pursuit of managerial efficiency should not compromise medium-term success in terms of product and business success (Albert et al., 2017; Artto et al., 2016; Zwikael \& Meredith, In Press). In reality, medium-term success should co-exist with short-term success constructs such as process and project management success.

\subsection{Long-term success}

Shenhar et al. (2001) conceptualised the timeframe of project success and argued business success as a long-term endeavour that propagates project benefits into organisational benefits. Zwikael et al. (2018) speak to three project benefit components: (i) specificity, (ii) attainability and (iii) comprehensiveness. IS projects apply the same philosophy as business success centres on ensuring the business motives of the project are met through the realisation of the business case and benefits (Bannerman \& Thorogood, 2012; Sulistiyani \& Tyas, 2019). A question arises regarding how do the short and medium-term dimensions of project success affect a long-term dimension that is traditionally assessed post-project (Albert et al., 2017). The business case is a key function of process and project management success as it provides the groundwork for the purpose and intent of the IS project while serving as a tool when monitoring and reviewing the benefits of the project (Einhorn et al., 2019). Regarding medium-term success, product success focuses on meeting and delivering on client and user expectations (Bannerman \& Thorogood, 2012). Through continuous consultation with these stakeholders, the IS project sustains and informs business success as they provide valuable insight regarding the practical implications of the ultimate project output (Hughes et al., 2019; Petter et al., 2013).

Projects are critical portfolio and programme elements that act as conduits for realising long-term strategic goals and objectives (Marnewick, 2016). Strategic success is, therefore, a construct projects must realise as this prepares the organisation for exploiting new markets and industries while achieving the competitive advantage (Joseph, 2017; Shenhar et al., 2001). Shenhar et al. (2001) argue that strategic success can only be determined after a period of about two to five years. Furthermore, studies such as Badewi (2016) and Luo et al. (2020) argue a moderate to weak correlation between project practices/processes and long-term success. Williams et al. (2019), however, argues the front-end of a project is pivotal for strategic success as this delineates the strategic complexities and implications of the project. This coincides with Pankratz and Basten (2018) who argue against treating the inner workings of IS projects as a black box that will miraculously churn out the expected strategic results. IS projects are redundant endeavours unless they align to the strategic objectives and trajectory of the organisation (Hoffmann et al., 2020). Moreover, Hoffmann et al. (2020) validated the need to match project efficiency to the underlying strategic imperative of an IS project as the effort required to execute the project is a function of the final output. IS projects are a function of intricate variables that have a symbiotic role in realising the dimensions of the continuum of project success (Marnewick et al., 2017).

The following hypotheses reflect the discussion above:

- H1a—Process success has a positive correlation on deliverable success. 
- H1b-Process success has a positive correlation on business success.

- H1c-Process success has a positive correlation on strategic success.

- H2-Deliverable success has a positive correlation on business success.

- H3a-Deliverable success has a positive correlation on strategic success.

- H3b-Business success has a positive correlation on strategic success.

This research takes a different approach to previous studies and focuses on understanding and determining the functional role and influence of the three dimensions and the underlying constructs of IS project success. The research objective is to determine the correlation between short, medium and long-term IS project success. That is, the objective is to determine how short-term success (process success) effects medium-term success (deliverable success and business success) and long-term success (strategic success. Furthermore, the effect of medium-term success is determined as well as the effect between medium and long-term success. Conversely, this research deliberately omitted project management success and the inherent association with the triple constraint. The triple constraint has become less of a major success construct over time given the more important focus on stakeholder satisfaction, business and strategic success (Atkinson, 1999; Radujković \& Sjekavica, 2017). Figure 2 illustrates the research model adopted in this research.

\section{RESEARCH METHODS}

A post-positive theoretical lens was adopted for this research as it allows for the objective perception of IS project success through multiple subjective views (Guba \& Lincoln, 1994). The research goal was not to create absolute laws governing IS project success but rather to create a new approximation of the reality faced in these projects (Creswell, 2014). Reality exists in multiple forms and this research aims to provide a new perspective of IS project success justified through the investigation and analysis of the hypotheses (Mertens, 2005). Selecting a research strategy is important once determining the adopted theoretical lens as it forms the plan of how researchers intend to achieve their research goal (Saunders et al., 2015). The research model (Figure 2) was developed using a deductive approach and the survey research strategy facilitates deductive analysis (Saunders et al., 2015). Furthermore, the research model has a predictive element as the intent is to determine the correlation and effect of IS project success dimensions on each other. The analysis and modelling of variable relationships are facilitated by surveys, which in turn assist predictive modelling as they acquire large datasets from large individual groups in a standardised manner (Fowler, 2009).

Operationalising the survey indicates how the questions were developed and presented to research participants (Olsen, 2012). The survey questions indicate the variables adopted in a research study (Reardon, 2006). The measures presented in Table 1 were grounded in studies 


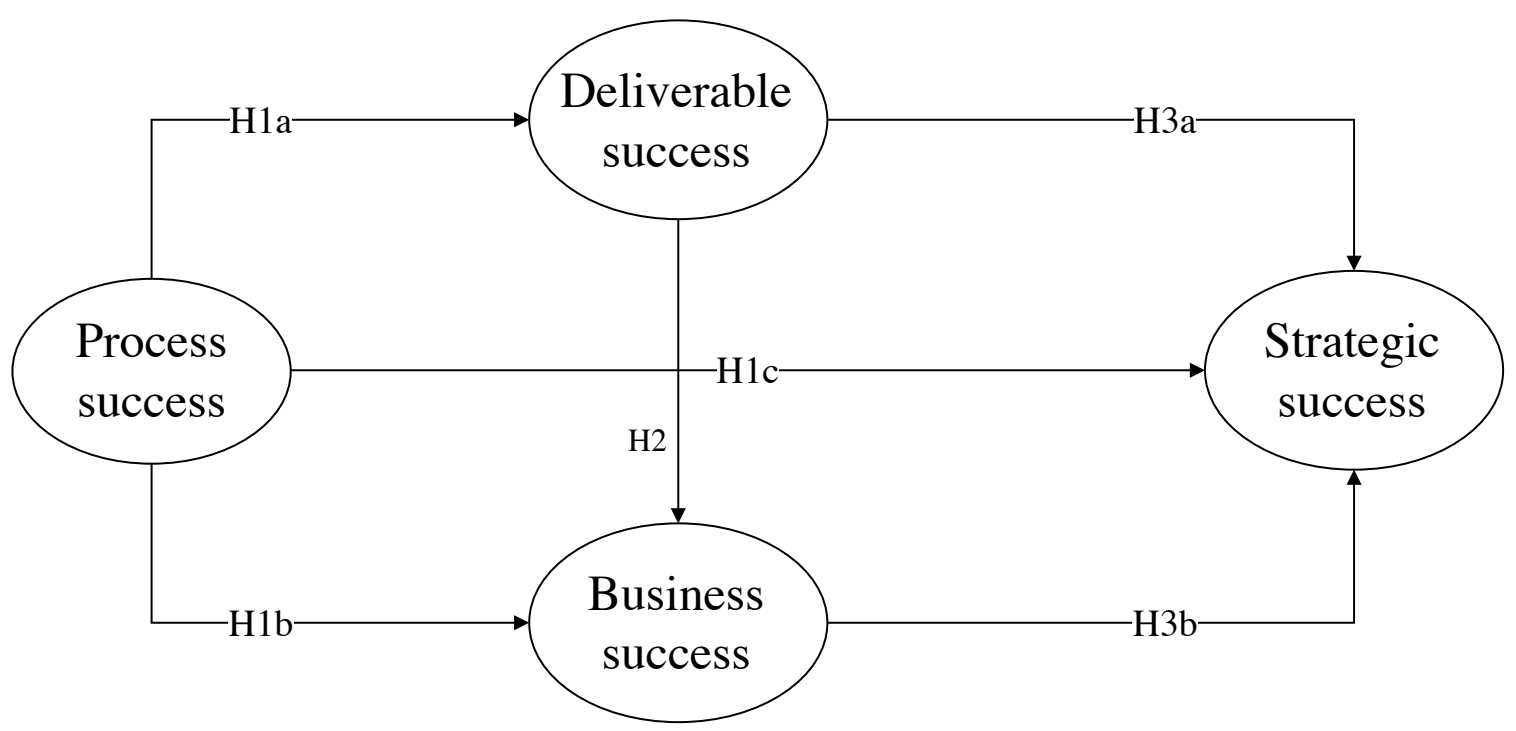

\begin{tabular}{ccc}
\hline $\begin{array}{c}\text { Short-term IS project } \\
\text { success }\end{array}$ & $\begin{array}{c}\text { Medium-term IS } \\
\text { project success }\end{array}$ & $\begin{array}{c}\text { Long-term IS project } \\
\text { success }\end{array}$
\end{tabular}

Figure 2: Research model for the continuum of IS project success

by Bannerman (2008), Bannerman and Thorogood (2012), Petter et al. (2013), Joseph (2017) and Sulistiyani and Tyas (2019). Table 1 maps each measure to their respective IS project success constructs and continuum dimension. Joia and Melon (2019) acknowledges the applicability and relevance of each dimension and argues an empirical validation of Bannerman and Thorogood (2012) in particular as they are yet to move past the conceptual phase.

The survey strategy was executed via an online questionnaire as it facilitates standardised and economic data collection from large populations (Saunders et al., 2015). The questions are consistent and transparent for all participants. A questionnaire link was posted on LinkedIn. Furthermore, a questionnaire link was posted on Twitter and included project management related handles (e.g. @PMInstitute, @APMProjectMgmt and @pmiagile) as these targeted individuals that follow project management related content on Twitter. Using social media as an avenue for data gathering allows researchers to post easy to access questionnaires online and gain insight from a diverse array of individuals (Leiner, 2014). This research was conducted over two years, 2017-2018.

Establishing validity and reliability is important in any research context. Validity focuses on the suitability of a measurement instrument to address the research problem reality (Saunders et al., 2015). Internal validity was achieved by deductively constructing the questionnaire using IS project success literature spanning more than two decades. Content validity was achieved as the questions and variables used in this research were assessed by academics 
Table 1: IS project success variables operationalised from literature. Adapted from Bannerman (2008), Bannerman and Thorogood (2012), Petter et al. (2013), Joseph (2017) and Sulistiyani and Tyas (2019)

\begin{tabular}{|c|c|c|c|}
\hline $\begin{array}{l}\text { Continuum } \\
\text { dimension }\end{array}$ & $\begin{array}{l}\text { Construct } \\
\text { (Reliability) }\end{array}$ & Measure & Indicator name \\
\hline \multirow{4}{*}{$\begin{array}{l}\text { Short-term } \\
\text { success }\end{array}$} & \multirow{4}{*}{$\begin{array}{l}\text { Process success } \\
(0.830) *\end{array}$} & $\begin{array}{l}\text { Appropriately chosen for the } \\
\text { intended purpose }\end{array}$ & PS_Chosen \\
\hline & & $\begin{array}{l}\text { Aligned with the project } \\
\text { objectives }\end{array}$ & PS_Alignment \\
\hline & & $\begin{array}{l}\text { Integrated with each other (as } \\
\text { appropriate) }\end{array}$ & PS_Integrated \\
\hline & & Effectively implemented & PS_Implemented \\
\hline \multirow{12}{*}{$\begin{array}{l}\text { Medium-term } \\
\text { success }\end{array}$} & \multirow{6}{*}{$\begin{array}{l}\text { Deliverable } \\
\text { success } \\
(0.904) *\end{array}$} & Specifications met & DS_Specifications \\
\hline & & Client/user expectations met & DS_User_Expectations \\
\hline & & Client/user acceptance & DS_User_Acceptance \\
\hline & & Product/system used & DS_Product_Used \\
\hline & & Client/user satisfied & DS_User_Satisfied \\
\hline & & Client/user benefits realised & DS_Benefits_Realised \\
\hline & \multirow{6}{*}{$\begin{array}{l}\text { Business success } \\
(0.798) *\end{array}$} & Goals/objectives & BS_Goals \\
\hline & & Business plan & BS_Business_Plan \\
\hline & & Governance & BS_Governance \\
\hline & & Benefits realisation & BS_Benefits_Realisation \\
\hline & & Unintended benefits & BS_Unintended_Benefits \\
\hline & & Unintended impacts & BS_Unintended_Impacts \\
\hline \multirow{7}{*}{$\begin{array}{l}\text { Long-term } \\
\text { success }\end{array}$} & \multirow{6}{*}{$\begin{array}{l}\text { Strategic success } \\
(0.851) *\end{array}$} & Market impact & SS_Market_Impact \\
\hline & & Industry impact & SS Industry Impact \\
\hline & & Competitive impact & SS_Competitive_Impact \\
\hline & & Investor impact & SS_Investor_Impact \\
\hline & & Regulator impact & SS_Regulator_Impact \\
\hline & & Other impact & SS_Other \\
\hline & & ch's Alpha reliability & \\
\hline
\end{tabular}

in the IS project management field. External validity explores the application of results to a research study. IS project team members who were actively involved in and implemented any IS projects across any industry were targeted. The rationale was that these individuals would have first-hand experience and knowledge regarding IS projects given their vested involvement. An overview of the respondents is presented in Figure 3 and Figure 4. Construct validity was established in this research by achieving the three previous pillars of validity. Reliability focuses on the consistency of data collected as the aim is to produce repeatable results under similar conditions (Dick, 2014). Each construct and their respective measures were initially assessed using the Cronbach's Alpha statistic. As indicated in Table 1, all constructs were above the 0.7 threshold (Field, 2018). 


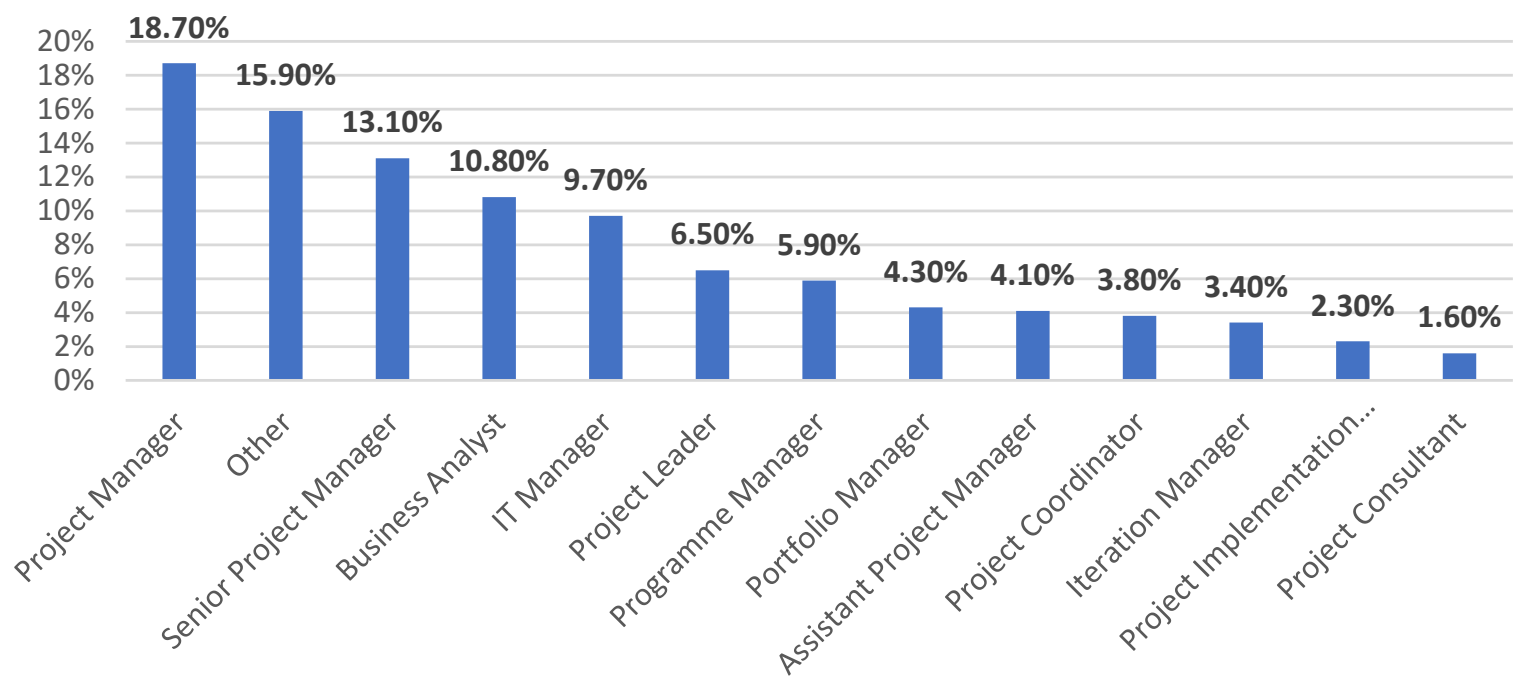

Figure 3: Job title demographics

\section{MODEL RESULTS}

A total of 612 valid responses were collected through the online questionnaire. Partial least squares structural equation modelling (PLS-SEM) was used as the analysis mechanism to assess the variable correlations and answer the research question. PLS-SEM is a powerful tool for exploratory research and for understanding correlation effects between constructs (Evermann \& Tate, 2016; Hair, Hollingsworth et al., 2017). Moreover, PLS-SEM has matured in the IS research field and has gained traction in multiple IS research endeavours (Hair, Hollingsworth et al., 2017). SmartPLS 3.2.9 was used to perform the PLS-SEM analysis as it is widely and successfully used in multiple fields including the project management field (e.g., Carvalho and Rabechini Jr (2017) and Bjorvatn and Wald (2018)).

Assessing the measurement model is the first step when performing PLS-SEM. The measurement model is defined as the connection between indicators/variables and latent constructs. As per Figure 2, process and strategic success were defined as the independent and dependent variables respectively. Furthermore, deliverable and business success were defined as both independent and dependent variables as they are influenced by process success while influencing strategic success.

Table 2 presents the final and accepted results of the measurement model. A key distinction in Table 2 is that two IS project success constructs merged, i.e., three latent constructs were established to support IS project success. Discriminate validity was an issue after three iterations as the Heterotrait-Monotrait ratio (HTMT) across the deliverable and business success constructs was above the 0.85 ceiling (Hair et al., 2019; Henseler et al., 2015). This implies the two constructs are conceptually comparable, and that they should be merged (Hair, Hult 


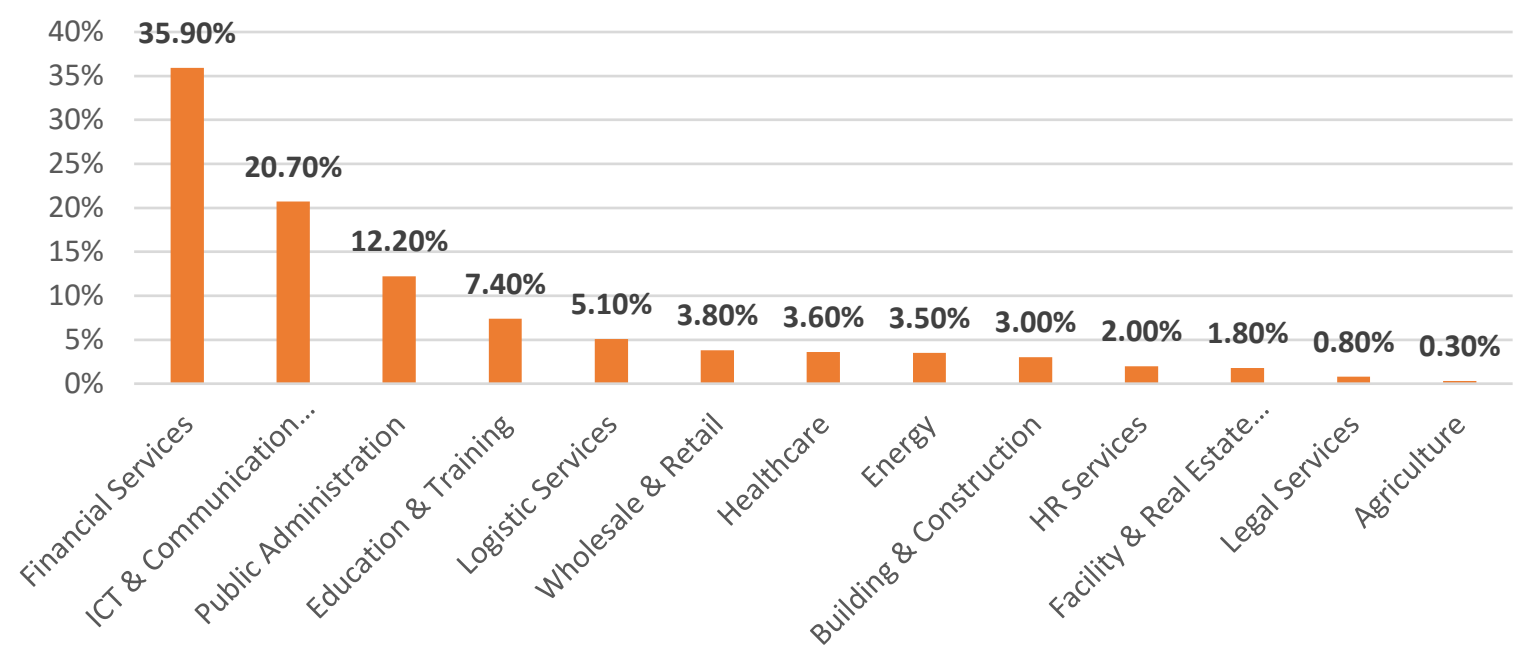

Figure 4: Industry representation

et al., 2017). The remaining indicators from business success were included in deliverable success and the business success construct was removed. The remaining acceptance criteria were as follows. Internal consistency reliability of all IS project success constructs was above the Cronbach's Alpha and composite reliability threshold of 0.7 (Hair, Hollingsworth et al., 2017; Hair et al., 2019). Convergent validity was accepted as the average variance extracted (AVE) and indicator loadings were above the 0.5 threshold (Hair et al., 2019; Ringle et al., 2018). Discriminant validity was confirmed through the assessment of the HTMT bias-corrected confidence intervals as each value should be below 1 (Hair et al., 2019; Henseler et al., 2015). 


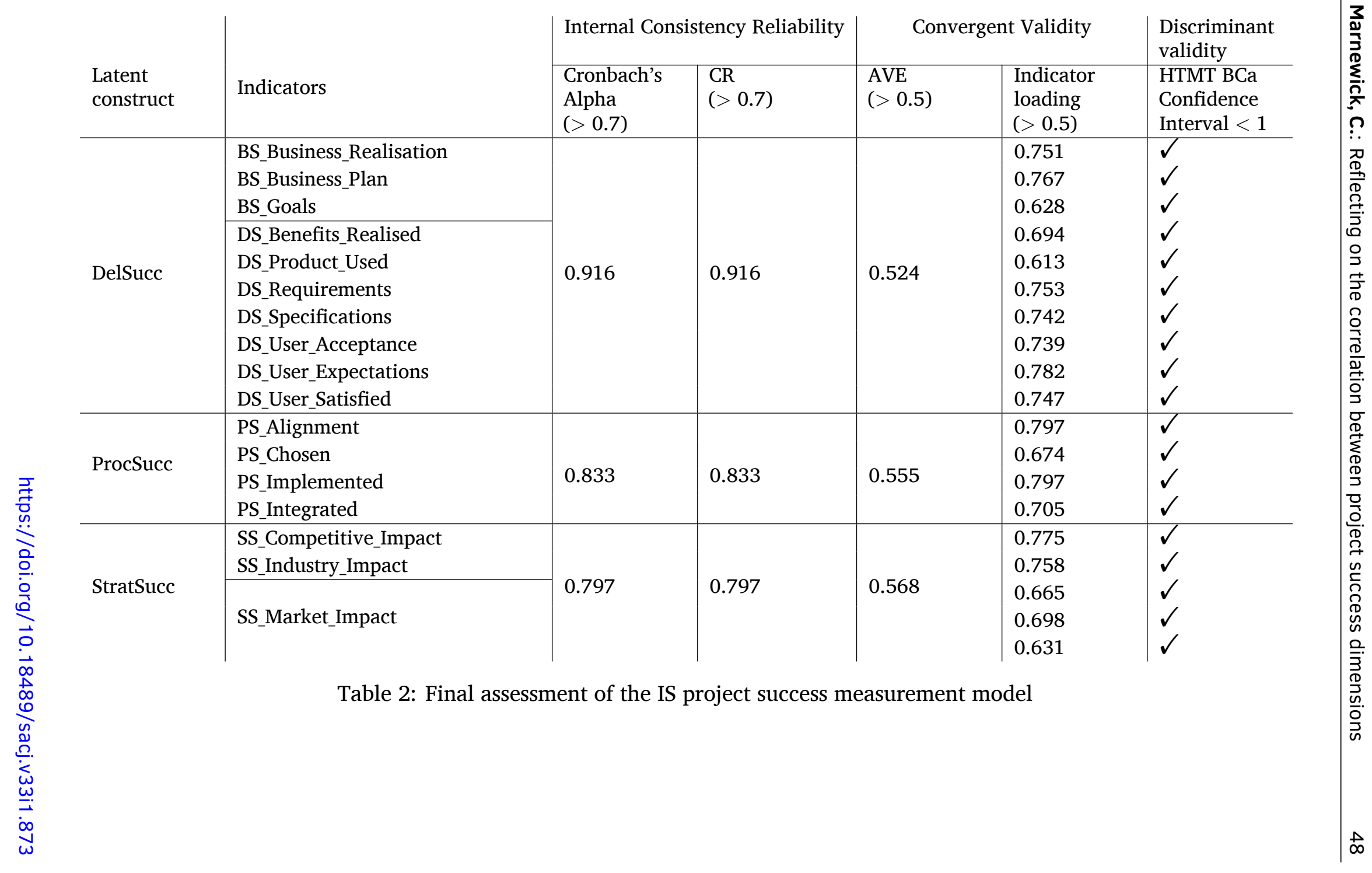


The next step is to assess the structural model, i.e., the results indicating the correlation between the latent constructs. Collinearity was assessed through the inner variation inflation factor (VIF) values and achieve values below 5 (Hair et al., 2019). The inner VIF values were all below the 5 threshold indicating that the latent constructs are unrelated. Table 3 presents the remaining results for assessing the structural model.

Table 3: Final assessment of IS project success structural model

\begin{tabular}{cc}
\hline Relationship & Path coefficient $*$ \\
\hline Process success $\rightarrow$ Deliverable success & $0.758(30.481 ; 0.000)[0.708,0.805]$ \\
Process success $\rightarrow$ Strategic success & $0.038(0.503 ; 0.615)[-0.117,0.187]$ \\
Deliverable success $\rightarrow$ Strategic success & $0.612(8.547 ; 0.000)[0.474,0.754]$ \\
Coefficient of determination & $R^{2}$ \\
Deliverable success & $0.575(15.265 ; 0.000)[0.501,0.647]$ \\
Strategic success & $0.411(9.123 ; 0.000)[0.329,0.505]$ \\
Effect size & $f^{2}$ \\
Process success $\rightarrow$ Deliverable success & $1.351(6.276 ; 0.000)[1.004,1.837]$ \\
Process success $\rightarrow$ Strategic success & $0.001(0.145 ; 0.885)[0.000,0.025]$ \\
Deliverable success $\rightarrow$ Strategic success & $0.271(3.380 ; 0.001)[0.145,0.458]$ \\
\hline$* t$-values and $p$-values are noted in parentheses - $(t$-value; $p$-value). Percentile bootstrap \\
confidence intervals are presented in brackets. \\
\hline
\end{tabular}

The path coefficients are interpreted as standardised regression coefficients (Benitez et al., 2020). The results indicate a significant correlation between process success and deliverable success. That is, a single standard deviation increase in process success will lead to a 0.758 (0.000) increase in deliverable success. This implies that the underlying processes used to execute IS projects have a significant role in determining customer satisfaction and business benefits. Short-term success, therefore, has an impact on medium-term success. Another significant correlation is between deliverable success and strategic success as a single standard deviation increase in deliverable success will lead to a $0.612(0.000)$ increase in strategic success. Long-term success is therefore significantly influenced by medium-term success as competitive, industry and market impacts are realised by the satisfaction of customers and direct business benefits. While there is no significant direct correlation between process success and strategic success, the results confirm an indirect correlation effect over time. That is, deliverable success mediates the impact of process success on strategic success in the long-term. The selection and execution of IS project processes are imperative as they have a long-term effect on underlying strategic initiatives and not only an immediate effect on project performance.

The coefficient of determination $\left(R^{2}\right)$ determines how well a latent construct is predicted by its respective predictor/s or influencing construct/s. The $R^{2}$ value indicates the per cent of variance explained in the predicted latent construct and can be explained as substantial (0.75), moderate (0.5) and weak (0.25) (Benitez et al., 2020; Hair et al., 2019). Process success, therefore, explains $57.5 \%$ of deliverable success. This implies that short-term success moderately predicts medium-term success. Similarly, deliverable success explains $41.1 \%$ of the variance in strategic success. While there is weak predictive strength between medium and 
long-term success, it could be argued and considered closer to moderate given the $R^{2}$ value's range proximity. In an attempt to explore the time effect of IS project success, these result can be considered valuable as the phenomena are explored further.

Benitez et al. (2020) argue that the practical relevance of the previous results should be contextual by assessing the effect size $\left(f^{2}\right)$ of the relationships between constructs. Similar to interpreting $R^{2}$ values, $f^{2}$ values of $0.02,0.15$ or 0.25 indicate a small, medium and large effect, respectively (Hair, Hollingsworth et al., 2017; Henseler et al., 2009). Process success has a large effect on deliverable success and confirms the impact of IS project processes on medium-term success. Deliverable success also has a large effect on strategic success and implies that medium-term success has a significant impact on long-term success. In line with path coefficient results, there is no significant correlation between process success on strategic success. This arguably confirms the indirect and mediating role of medium-term success between short and long-term IS project success. Through all the above results, it is clear that IS project success is a continuum and success manifests over time through the three dimensions of IS project success.

\section{DISCUSSION AND CONCLUSIONS}

Interrogating each of the IS project success construct indicators reveals several key findings (Table 2). The following implications relate to process success. Firstly, process success is understood through the correct alignment of project processes and project objectives. This coincides with the notion that there should be process alignment to ensure that the project realises its goals and the greater strategic initiative (Gerow et al., 2014; Marnewick et al., 2017). Secondly, effective implementation of processes also explains process success. Correct implementation of processes facilitates cohesion, collaboration and productivity during the project life cycle (Galvan et al., 2015; Ozguler, 2016). Selecting the correct processes for IS projects is tricky as there are a plethora of traditional and agile approaches available with no single panacea for all IS project types (Marnewick et al., 2017; Petersen \& Wohlin, 2010).

Regarding deliverable success, several themes were revealed. The first theme centres on IS projects delivering on the business problem or initiative. The deliverables of an IS project should have a clear focus and intent among clients and/or users (Cooke-Davies, 2002; Joseph et al., 2014). Exploiting deliverable success is imperative to gain a stronger competitive footing in the market and industry an organisation operates. This is also facilitated by meeting user expectations and satisfaction. This theme is widely debated in literature as the users can dictate whether an IS project is a failure or a success (Bradford \& Oya, 2018; Joseph et al., 2014; Petter et al., 2013). The output of an IS project can be rejected if underutilised by users and the initiative will be questioned if benefits are not realised (Bradford \& Oya, 2018; Marnewick et al., 2017). It is imperative to include users during the IS project development cycle to facilitate improved user experience (Marnewick et al., 2017; Serrador \& Pinto, 2015). The final theme identified in deliverable success pertains to requirements management. IS projects are notorious for specification and requirements issues (Group, 2018; Joseph et al., 
2014). Defining specifications and requirements serve as a benchmark during IS projects and the challenge is to ensure they are evident and achieve the underlying intent of the project (Bradford \& Oya, 2018; Schön et al., 2019).

The overall theme of strategic success pertains to the competitive, industry and market impact the IS project will have over time. Achieving strategic success is the long-term goal of any IS project because strategic intent drives IS project initiatives (Farhanghi et al., 2013; Kalkan et al., 2011). The output of IS projects has a strong impact on organisational performance (Yunis et al., 2018; Zaman et al., 2019). IS projects play a critical part in achieving and maintaining competitive advantage within the organisation's industry and market (Weber \& Kauffman, 2011; Yunis et al., 2018).

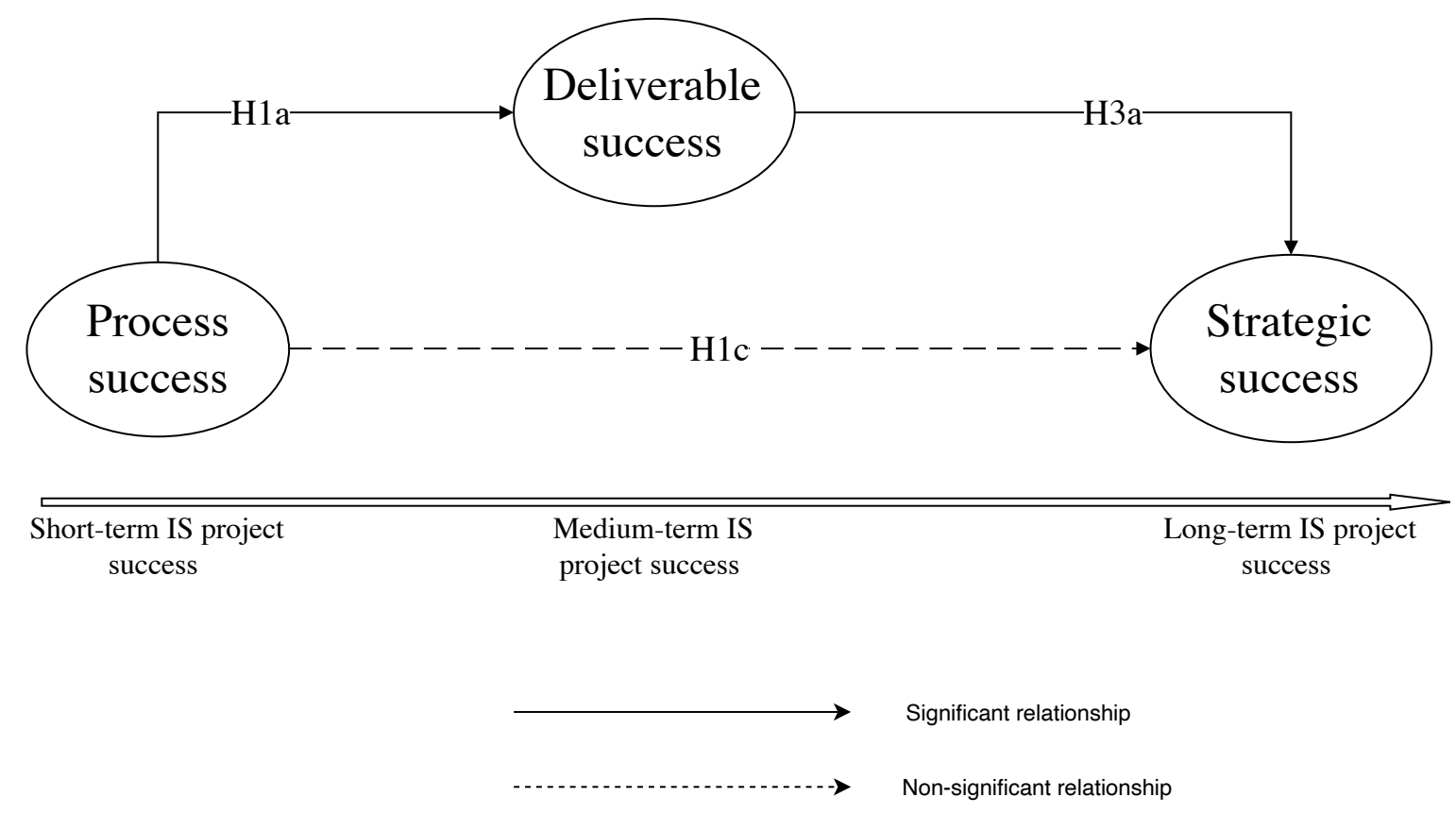

Figure 5: Revised research model

Figure 5 reflects the revised research model developed from the results. The "Fata Morgana" or mirage effect of distorted success over time is arguably less of an issue when the correlation between the time dimensions of IS project success are better understood. Reflecting on the hypotheses and the results of Table 3, the following conclusions are drawn. Hypothesis $\mathrm{H} 1 \mathrm{a}$ is accepted as process success has a significant and positive correlation on deliverable success. Conversely, hypothesis $\mathrm{H} 1 \mathrm{c}$ is rejected as process success has no significant correlation on strategic success. Interestingly, hypotheses $\mathrm{H} 1 \mathrm{~b}, \mathrm{H} 2$ and $\mathrm{H} 3 \mathrm{~b}$ are classified as redundant as the PLS-SEM process merged deliverable and business success given their proximity and comparability conceptually. Regarding hypothesis H3a, the premise is true as there was a significant and positive correlation between deliverable success and strategic success. The 
overall implication is that short-term IS project success does not directly impact long-term IS project success. However, there is a clear correlation between the time phases of IS project success as this research shows medium-term success mediates the correlation relationship and impact of short and long-term success. While the relationship has been acknowledged in literature (Pinkerton, 2003; Shenhar et al., 2001), this research confirms this notion and proves that there is a significant effect between each IS project success dimension over time. This research corresponds with the revelation of a moderate to a weak relationship between short and long-term success but within the IS project domain (Badewi, 2016; Luo et al., 2020). This research also expands on previous studies by revealing the large effect between short, medium and long-term IS project success. The mediating role of deliverable success/mediumterm success cannot be ignored as this indicates the importance of project managers ensuring symbiosis of pre, present and post IS project activities. IS project success is a continuum and success manifests over time through the three time dimensions of IS project success.

\subsection{Limitations and future research}

Every research endeavour is not without limitations. Firstly, the dataset was mainly representative of the financial services and ICT and communication services industry. While these industries are known for their implementation of IS projects, future research should gain views from other industries as this could paint a different picture. Secondly, the project management success (triple constraint) construct was excluded from this research. Including this construct in future studies could reveal the impact or moderating role of the triple constraint over time. The third limitation concerns the variance explained for process, deliverable and strategic success constructs. Exploring areas such as the socio-technical construct in future research could add value to the current predictive model and further explain the constructs of success. Finally, the results pertain to IS projects in general and do not make provision or distinguish between the various IS project methodologies, e.g., agile vs traditional. Future research should explore this possibility, which would add to the debate about whether the agile philosophy is more effective for IS projects.

\section{References}

Albert, M., Balve, P. \& Spang, K. (2017). Evaluation of project success: A structured literature review. International Journal of Managing Projects in Business, 10(4), 796-821. doi:10. 1108/IJMPB-01-2017-0004

Archibald, R. D., Filippo, I. D. \& Filippo, D. D. (2012). The six-phase comprehensive project life cycle model including the project incubation/feasibility phase and the post-project evaluation phase. Project Management World Journal, 1(5), 1-40.

Armenia, S., Dangelico, R. M., Nonino, F. \& Pompei, A. (2019). Sustainable project management: A conceptualization-oriented review and a framework proposal for future studies. Sustainability, 11(9), 2664-2679. 
Artto, K., Ahola, T. \& Vartiainen, V. (2016). From the front end of projects to the back end of operations: Managing projects for value creation throughout the system lifecycle. International Journal of Project Management, 34(2), 258-270. http:// dx. doi.org/10. 1016/j.ijproman.2015.05.003

Atkinson, R. (1999). Project management: Cost, time and quality, two best guesses and a phenomenon, its time to accept other success criteria. International Journal of Project Management, 17(6), 337-342. https://doi.org/10.1016/S0263-7863(98)00069-6

Baccarini, D. (1999). The logical framework method for defining project success. Project Management Journal, 30(4), 25-32.

Badewi, A. (2016). The impact of project management (pm) and benefits management (bm) practices on project success: Towards developing a project benefits governance framework. International Journal of Project Management, 34(4), 761-778. http://dx.doi.org/ 10.1016/j.ijproman.2015.05.005

Bannerman, P. (2008). Defining project success: A multilevel framework. Proceedings of the Project Management Institute Research Conference, 1-14.

Bannerman, P. \& Thorogood, A. (2012). Celebrating it projects success: A multi-domain analysis. 45th Hawaii International Conference on System Sciences, 4874-4883. 10.1109/ HICSS.2012.147

Benitez, J., Henseler, J., Castillo, A. \& Schuberth, F. (2020). How to perform and report an impactful analysis using partial least squares: Guidelines for confirmatory and explanatory is research. Information \& Management, 57(2), 103168. https://doi.org/10.1016/ j.im.2019.05.003

Bjorvatn, T. \& Wald, A. (2018). Project complexity and team-level absorptive capacity as drivers of project management performance. International Journal of Project Management, 36(6), 876-888. https://doi.org/10.1016/j.ijproman.2018.05.003

Bradford, E. \& Oya, T. (2018). Business user impact on information system projects. International Journal of Managing Projects in Business, 11(2), 289-316. doi:10.1108/IJMPB-022017-0016

Brady, T., Davies, A. \& Gann, D. M. (2005). Creating value by delivering integrated solutions. International Journal of Project Management, 23(5), 360-365. https://doi.org/10.1016/ j.ijproman.2005.01.001

Carvalho, M. M. \& Rabechini Jr, R. (2017). Can project sustainability management impact project success? an empirical study applying a contingent approach. International Journal of Project Management, 35(6), 1120-1132. https://doi.org/10.1016/j.ijproman.2017. 02.018

Cooke-Davies, T. (2002). The "real" success factors on projects. International Journal of Project Management, 20(3), 185-190. http://dx.doi.org/10.1016/S0263-7863(01)00067-9

Creswell, J. (2014). Research design: Qualitative, quantitative and mixed methods approaches. SAGE. 
Davis, K. (2014). Different stakeholder groups and their perceptions of project success. International Journal of Project Management, 32(2), 189-201. 10.1016/j.ijproman.2013.02. 006

Dick, B. (2014). Reliability. In D. Coghlan \& M. Brydon-Miller (Eds.), The sage encyclopedia of action research (pp. 683-685). SAGE. 10.4135/9781446294406

Einhorn, F., Marnewick, C. \& Meredith, J. (2019). Achieving strategic benefits from business it projects: The critical importance of using the business case across the entire project lifetime. International Journal of Project Management, 37(8), 989-1002. https://doi.org/ 10.1016/j.ijproman.2019.09.001

Evermann, J. \& Tate, M. (2016). Assessing the predictive performance of structural equation model estimators. Journal of Business Research, 69(10), 4565-4582. https://doi.org/10. 1016/j.jbusres.2016.03.050

Farhanghi, A. A., Abbaspour, A. \& Ghassemi, R. A. (2013). The effect of information technology on organizational structure and firm performance: An analysis of consultant engineers firms (cef) in iran. Procedia - Social and Behavioral Sciences, 81, 644-649. 10.1016/j. sbspro.2013.06.490

Field, A. (2018). Discovering statistics using ibm spss statistics. SAGE. http://books.google.co. za/books?id=srb0a9fmMEoC

Fleron, B. R., Hansen, M. R. P. \& Pries-Heje, J. (2019). Is success in IT projects a Fata Morgana? - A case study of a large healthcare IT project [Last accessed 20 June 2021]. https: //aisel.aisnet.org/scis2019/10

Fowler, F. (2009). Survey research methods (4th). SAGE. 10.4135/9781452230184

Galvan, S., Mora, M., O’Connor, R. V., Acosta, F. \& Alvarez, F. (2015). A compliance analysis of agile methodologies with the iso/iec 29110 project management process. Procedia Computer Science, 64, 188-195. http://dx.doi.org/10.1016/j.procs.2015.08.480

Gerow, J. E., Grover, V., Thatcher, J. \& Roth, P. L. (2014). Looking toward the future of itbusiness strategic alignment through the past: A meta-analysis. MIS Quarterly, 38(4), 1059-1085.

Group, S. (2018). Chaos report series - decision latency theory: It is all about the interval (Report). Guba, E. \& Lincoln, Y. S. (1994). Competing paradigms in qualitative research. In N. K. Denzin \& Y. S. lincoln (Eds.), Handbook of qualitative research (pp. 105-117). Sage.

Hair, J., Hollingsworth, C. L., Randolph, A. B. \& Chong, A. Y. L. (2017). An updated and expanded assessment of pls-sem in information systems research. Industrial Management \& Data Systems, 117(3), 442-458. doi:10.1108/IMDS-04-2016-0130

Hair, J., Hult, G. T. M., Ringle, C. M. \& Sarstedt, M. (2017). A primer on partial least squares structural equation modeling (pls-sem) (2e). SAGE.

Hair, J., Risher, J. J., Sarstedt, M. \& Ringle, C. M. (2019). When to use and how to report the results of pls-sem. European Business Review, 31(1), 2-24. doi:10.1108/EBR-11-20180203 
Henseler, J., Ringle, C. M. \& Sarstedt, M. (2015). A new criterion for assessing discriminant validity in variance-based structural equation modeling. Journal of the Academy of Marketing Science, 43(1), 115-135. 10.1007/s11747-014-0403-8

Henseler, J., Ringle, C. M. \& Sinkovics, R. R. (2009). The use of partial least squares path modeling in international marketing. In R. Sinkovics \& P. Ghuari (Eds.), New challenges to international marketing (pp. 277-319). Emerald Group Publishing. doi:10.1108/ S1474-7979(2009)0000020014

Hoffmann, D., Ahlemann, F. \& Reining, S. (2020). Reconciling alignment, efficiency, and agility in it project portfolio management: Recommendations based on a revelatory case study. International Journal of Project Management, 38(2), 124-136. https://doi.org/10. 1016/j.ijproman.2020.01.004

Hughes, D. L., Rana, N. P. \& Dwivedi, Y. K. (2019). Elucidation of is project success factors: An interpretive structural modelling approach. Annals of Operations Research. 10.1007/ s10479-019-03146-w

Ika, L. A. (2009). Project success as a topic in project management journals. Project Management Journal, 40(4), 6-19. 10.1002/pmj.20137

Joia, L. A. \& Melon, M. (2019). The social representation of success in it projects. International Journal of Managing Projects in Business, 13(7), 1578-1599.

Joseph, N. (2017). Conceptualising a multidimensional model of information communication and technology project complexity. South African Journal of Information Management, 19(1), 1-14. http://www.sajim.co.za/index.php/SAJIM/article/view/825

Joseph, N., Erasmus, W. \& Marnewick, C. (2014). The idle state of information and communication technology project management. Journal of African Business, 15(3), 184-196. 10.1080/15228916.2014.956641

Kalkan, A., Erdil, O. \& Çetinkaya, Ö. (2011). The relationships between firm size, prospector strategy, architecture of information technology and firm performance. Procedia - Social and Behavioral Sciences, 24, 854-869. 10.1016/j.sbspro.2011.09.114

Leiner, D. (2014). Convenience samples from online respondent pools: A case study of the sosci panel. International Journal of Internet Science, 20(5), 1-18.

Luo, L., Zhang, L. \& He, Q. (2020). Linking project complexity to project success: A hybrid sem-fcm method. Engineering, Construction and Architectural Management, 27(9), 25912614. 10.1108/ECAM-05-2019-0241

Marnewick, C., Erasmus, W. \& Joseph, N. (2017). The symbiosis between information system project complexity and information system project success. AOSIS (Pty) Ltd. https:// doi. org/10.4102/aosis.2017.itpsc45

Marnewick, C. (2016). Benefits of information system projects: The tale of two countries. International Journal of Project Management, 34(4), 748-760. http://dx.doi.org/10.1016/ j.ijproman.2015.03.016

Mertens, D. (2005). Research and evaluation in education psychology: Integrating diversity with quantitative, qualitative, and mixed methods. Sage.

Microsoft Corporation. (2013). Sure step to customer through partner overview. 
Mirza, M. N., Pourzolfaghar, Z. \& Shahnazari, M. (2013). Significance of scope in project success. Procedia Technology, 9, 722-729. http://dx.doi.org/10.1016/j.protcy.2013. 12.080

Musil, J. \& Hoeliner, R. (2009). The new asap methodology.

Nguyen, T. D., Nguyen, T. M. \& Cao, T. H. (2017). A conceptual framework for is project success. In P. Cong Vinh, L. Tuan Anh, N. T. T. Loan \& W. Vongdoiwang Siricharoen (Eds.), Context-aware systems and applications: 5th international conference, iccasa 2016, thu dau mot, vietnam, november 24-25, 2016, proceedings (pp. 142-154). Springer International Publishing. 10.1007/978-3-319-56357-2_15

Olsen, W. (2012). Data collection: Key debates and methods in social research. SAGE. 10.4135/ 9781473914230

Oracle Corporation. (2015). http://www.oracle.com/us/products/consulting/resourcelibrary/oracle-unified-method-069204.pdf

Ozguler, I. S. (2016). Increase the projects' success rate through developing multi-cultural project management process. Procedia - Social and Behavioral Sciences, 226, 236-242. http://dx.doi.org/10.1016/j.sbspro.2016.06.184

Pankratz, O. \& Basten, D. (2018). Opening the black box: Managers' perceptions of is project success mechanisms. Information \& Management, 55(3), 381-395. https:// doi.org/10. 1016/j.im.2017.09.005

Petersen, K. \& Wohlin, C. (2010). Software process improvement through the lean measurement (spi-leam) method. Journal of Systems and Software, 83(7), 1275-1287. http://dx. doi.org/10.1016/j.jss.2010.02.005

Petter, S., Delone, W. \& McLean, E. (2008). Measuring information systems success: Models, dimensions, measures, and interrelationships. European Journal of Information Systems, 17(3), 236-263. http://dx.doi.org/10.1057/ejis.2008.15

Petter, S., DeLone, W. \& McLean, E. R. (2013). Information systems success: The quest for the independent variables. Journal of Management Information Systems, 29(4), 7-62. 10. 2753/MIS0742-1222290401

Pinkerton, W. (2003). Project management: Achieving project bottom-line success. McGraw-Hill Education. http://books.google.co.za/books?id=KdBbIJyhpPcC

Radujković, M. \& Sjekavica, M. (2017). Project management success factors. Procedia Engineering, 196, 607-615. https://doi.org/10.1016/j.proeng.2017.08.048

Reardon, D. F. (2006). Doing your undergraduate project. SAGE. 10.4135/9781849209076

Ringle, C. M., Sarstedt, M., Mitchell, R. \& Gudergan, S. P. (2018). Partial least squares structural equation modeling in hrm research. The International Journal of Human Resource Management, 1-27. 10.1080/09585192.2017.1416655

Saad, M., Cicmil, S. \& Greenwood, M. (2002). Technology transfer projects in developing countries-furthering the project management perspectives. International Journal of Project Management, 20(8), 617-625. https://doi.org/10.1016/S0263-7863(02)000248 
Saunders, M., Lewis, P. \& Thornhill, A. (2015). Research methods for business students (Vol. Seventh edition). Pearson. http://0-search.ebscohost.com.ujlink.uj.ac.za/login.aspx? direct $=$ true $\& \mathrm{db}=$ nlebk\&AN $=1419381 \&$ site $=$ ehost-live $\&$ scope $=$ site

Schön, E.-M., Sedeño, J., Mejías, M., Thomaschewski, J. \& Escalona, M. J. (2019). A metamodel for agile requirements engineering. Journal of Computer and Communications, 07, 85106. $10.4236 /$ jcc. 2019.72007

Serrador, P. \& Pinto, J. K. (2015). Does agile work? - a quantitative analysis of agile project success. International Journal of Project Management, 33(5). http://dx.doi.org/10.1016/ j.ijproman.2015.01.006

Shenhar, A. J., Dvir, D., Levy, O. \& Maltz, A. C. (2001). Project success: A multidimensional strategic concept. Long Range Planning, 34(6), 699-725. http://dx.doi.org/10.1016/ S0024-6301(01)00097-8

Sulistiyani, E. \& Tyas, S. Y. (2019). Success measurement framework for information technology project: A conceptual model. 2019 International Conference on Computer Science, Information Technology, and Electrical Engineering (ICOMITEE), 43-48. 10.1109/ ICOMITEE.2019.8921174

Thomas, G. \& Fernández, W. (2008). Success in it projects: A matter of definition? International Journal of Project Management, 26(7), 733-742. http://dx.doi.org/10.1016/j.ijproman. 2008.06.003

Wateridge, J. (1995). It projects: A basis for success. International Journal of Project Management, 13(3), 169-172. http://dx.doi.org/10.1016/0263-7863(95)00020-Q

Wateridge, J. (1998). How can is/it projects be measured for success? International Journal of Project Management, 16(1), 59-63. http://dx.doi.org/10.1016/S0263-7863(97) 00022-7

Weber, D. M. \& Kauffman, R. J. (2011). What drives global ict adoption? analysis and research directions. Electronic Commerce Research and Applications, 10(6), 683-701. 10.1016/j. elerap.2011.01.001

Williams, T., Vo, H., Samset, K. \& Edkins, A. (2019). The front-end of projects: A systematic literature review and structuring. Production Planning \& Control, 1-31. 10.1080/ 09537287.2019.1594429

Yap, J. B. H., Skitmore, M., Gray, J. \& Shavarebi, K. (2019). Systemic view to understanding design change causation and exploitation of communications and knowledge. Project Management Journal, 50(3), 288-305. 10.1177/8756972819829641

Yunis, M., Tarhini, A. \& Kassar, A. (2018). The role of ict and innovation in enhancing organizational performance: The catalysing effect of corporate entrepreneurship. Journal of Business Research, 88, 344-356. https://doi.org/10.1016/j.jbusres.2017.12.030

Zaman, U., Jabbar, Z., Nawaz, S. \& Abbas, M. (2019). Understanding the soft side of software projects: An empirical study on the interactive effects of social skills and political skills on complexity - performance relationship. International Journal of Project Management, 37(3), 444-460. https://doi.org/10.1016/j.ijproman.2019.01.015 
Zwikael, O., Chih, Y.-Y. \& Meredith, J. R. (2018). Project benefit management: Setting effective target benefits. International Journal of Project Management, 36(4), 650-658. https://doi. org/10.1016/j.ijproman.2018.01.002

Zwikael, O. \& Meredith, J. (In Press). Evaluating the success of a project and the performance of its leaders. IEEE Transactions on Engineering Management, 1-13. 10.1109/TEM.2019. 2925057

Zwikael, O. \& Meredith, J. R. (2018). Who's who in the project zoo? the ten core project roles. International Journal of Operations \& Production Management, 38(2), 474-492. 10.1108/ IJOPM-05-2017-0274 